\title{
Detection and activity of 11 beta hydroxylase (CYP11B1) in the bovine ovary
}

\author{
A N Amweg, F M Rodríguez, E Huber, B E Marelli, N C Gareis, E M Belotti, F Rey, \\ N R Salvetti and H H Ortega \\ Instituto de Ciencias Veterinarias del Litoral (ICiVet-Litoral), Universidad Nacional del Litoral (UNL) - Consejo \\ Nacional de Investigaciones Científicas y Tecnológicas (CONICET), Esperanza, Santa Fe, Argentina \\ Correspondence should be addressed to H H Ortega; Email: hhortega@fcv.unl.edu.ar
}

\begin{abstract}
Glucocorticoids (GCs) such as cortisol and corticosterone are important steroid hormones with different functions in intermediate metabolism, development, cell differentiation, immune response and reproduction. In response to physiological and immunological stress, adrenocorticotropic hormone (ACTH) acts on the adrenal gland by stimulating the synthesis and secretion of GCs. However, there is increasing evidence that GCs may also be synthesized by extra-adrenal tissues. Here, we examined the gene and protein expression of the enzyme 11 -hydroxylase P450c11 (CYP11B1), involved in the conversion of 11-deoxycortisol to cortisol, in the different components of the bovine ovary and determined the functionality of CYP11B1 in vitro. CYP11B1 mRNA was expressed in granulosa and theca cells in small, medium and large antral ovarian follicles, and CYP11B1 protein was expressed in medium and large antral follicles. After stimulation by ACTH, we observed an increased secretion of cortisol by the wall of large antral follicles. We also observed a concentration-dependent decrease in the concentration of cortisol in response to metyrapone, an inhibitor of CYP11B1. This decrease was significant at $10^{-5} \mu \mathrm{M}$ metyrapone. In conclusion, this study demonstrated for the first time the presence of CYP11B1 in the bovine ovary. This confirms that there could be a local synthesis of GCs in the bovine ovary and therefore a potential endocrine responder to stress through these hormones.

Reproduction (2017) 153 433-441
\end{abstract}

\section{Introduction}

Glucocorticoids (GCs) are steroid hormones synthesized in the adrenal cortex during emotional or physical stress. Their production is regulated by the hypothalamicpituitary-adrenal (HPA) axis, more specifically, by the production of corticotropin-releasing hormone $(\mathrm{CRH})$ in the hypothalamus and of adrenocorticotropic hormone $(\mathrm{ACTH})$ in the anterior pituitary (Dejager et al. 2014). ACTH acts on the adrenal gland to increase the production and release of corticosterone, the main physiological GC in rats and mice, and cortisol, the main GC in mammals like humans and cows including other kinds of rodents (for example, the guinea pig, cavies and capybara) (Nemeth et al. 2014, Magomedova \& Cummins 2016). GCs regulate the basal activity of the HPA axis and modulate the stress response by acting mainly at the hypothalamus and pituitary gland, through a negative feedback on the secretion of $\mathrm{CRH}$ and $\mathrm{ACTH}$ respectively (Charmandari et al. 2005).

GCs act through the glucocorticoid receptor, a member of the nuclear steroid receptor superfamily (Nicolaides et al. 2010), and are essential for normal physiological function due to their regulatory effects on intermediate metabolism, development, cell differentiation, immune response and reproduction (Davies \& MacKenzie 2003, Duong et al. 2012, Dejager et al. 2014, Magomedova \& Cummins 2016). GCs are also anti-inflammatory agents that act to modulate the production of cytokines and prostaglandins in different reproductive processes: ovulation, luteolysis, embryo implantation, fetal growth and placental development (Hillier \& Tetsuka 1998, Andersen 2002, Myers et al. 2007, Tetsuka et al. 2010, Duong et al. 2012, Majewska et al. 2012, Kuse et al. 2013).

In response to stress, ACTH binds to its specific melanocortin receptor 2 (MC2R), a G-protein-coupled receptor, and activates the adenylyl cyclase cascade, leading to CAMP production and CAMP-dependent protein kinase activation, triggering the internal signaling cascade that is essential for the expression of steroidogenic enzymes and production of cortisol (Xing et al. 2010, Novoselova et al. 2013, Asser et al. 2014). In this sense, the conversion of cholesterol to pregnenolone occurs via the action of the cholesterol side chain cleavage cytochrome P450 (CYP11A1). After the activation of several enzymes, the final step 
in cortisol biosynthesis takes place in mitochondria and involves the conversion of 11-deoxycortisol to cortisol by the enzyme 11ß-hydroxylase P450c11 (CYP11B1) (Hu et al. 2010, Xing et al. 2010). This enzyme, which is a member of the cytochrome P450 (P450) superfamily, has been extensively studied in mammals (Schiffer et al. 2015). In cattle, studies have revealed that the bovine genome encodes five CYP11B1 genes. Three of these represent pseudogenes and the two functional genes encode two distinct CYP11B1 variants, but with only slight functional varieties (Schiffer et al. 2015).

Classically, it has been described that GCs are synthesized exclusively in the adrenal gland in response to stimulation by ACTH. However, several studies have shown that these hormones are also synthesized locally in other organs and tissues (Taves et al. 2011). In the gut, for example, CYP11B1 is expressed at low levels under basal conditions, and GCs are produced in reduced amounts, possibly fulfilling important functions in the regulation of immune homeostasis and epithelial layer integrity (Taves et al. 2011, Kostadinova et al. 2014). It has also been shown that epidermal keratinocytes express CYP11B1 and synthesize and secrete cortisol, probably to provide control of the initial proinflammatory response and prevent excessive inflammation upon tissue injury (Taves et al. 2011, Vukelic et al. 2011). CYP11B1 is also expressed in different cells of the brain and cardiovascular system (Davies \& MacKenzie 2003, Schmidt et al. 2009, Taves et al. 2011).

The access of active cortisol to target tissues is regulated by the relative expression of two $11 \beta$-hydroxysteroid dehydrogenase (11BHSD) enzymes: a bidirectional 11BHSD type 1 (11BHSD1), which mainly activates cortisone to cortisol, and 11BHSD type 2 (11BHSD2), which inactivates cortisol to cortisone (Krozowski et al. 1999, Tetsuka et al. 2003). In the ovary, both luteinized human granulosa cells (Michael et al. 1997) and cumulus cells (Simerman et al. 2015) generate cortisol from cortisone via 11BHSD1 action to regulate lipid metabolism in the maturing ovarian follicle, crucial for optimal oocyte maturation. Also, both $11 B H S D 1$ and 11 BHSD2 mRNAs have been identified in the bovine ovary (Tetsuka et al. 2003, Amweg et al. 2013), and their expression and activity have been associated with follicular development and maturation (Thurston et al. 2007, Tetsuka et al. 2010). This suggests that cortisol might be involved in regulatory mechanisms related to ovarian function associated with ovulation, steroidogenesis and luteal function (Tetsuka 2007, Amweg et al. 2011, 2013). In addition, although it has not been demonstrated that the ovary is able to produce GCs de novo, ACTH is able to stimulate the secretion of cortisol in bovine ovarian follicles in vitro (Amweg et al. 2011, 2013).

Considering this premise, the aim of the present study was to evaluate the expression of CYP11B1 in different components of the bovine ovary and to determine the in vitro activity of CYP11B1.

\section{Materials and methods}

\section{Ethical aspects}

All the procedures were carried out according to the 'Guide for the Care and Use of Agricultural Animals in Agricultural Research and Teaching' (2010) and with the approval of the Institutional Ethics and Security Committee of the Facultad de Ciencias Veterinarias, Universidad Nacional del Litoral, Argentina (Protocol N 67/10).

\section{Collection and preparation of tissues}

Ovaries from 40 randomly cycling Argentinean Holstein cows, assessed visually as non-pregnant, with no apparent abnormality in the reproductive system, and with normal follicular activity (i.e. ovaries macroscopically showing different stages of follicles and without active corpora lutea) were collected at a local abattoir, within $20 \mathrm{~min}$ after death and quickly transported to the laboratory in conservative boxes with refrigerants over a period of time no longer than $60 \mathrm{~min}$. Also, adrenal samples were collected from five cows and were used as positive controls.

In the laboratory, each pair of ovaries was washed, and then, the antral follicles were removed using scissors and scalpel dissection. Antral follicles from normal cycling cows were classified into three categories according to their diameters as described previously (Parrott \& Skinner 1998): small $(<5 \mathrm{~mm}$, $n=15)$, medium (5-10 mm, $n=15$ ) or large ( $>10 \mathrm{~mm}, n=15)$. Follicles with an obviously atretic appearance (avascular theca and debris in the antrum) were discarded. At the laboratory, for RT-PCR and real-time PCR, granulosa cells were obtained by centrifugation of follicular fluid, aspirated with a syringe from the different antral follicles and immediately frozen at $-80^{\circ} \mathrm{C}$ until total RNA extraction. The follicular fluid was stored at $-20^{\circ} \mathrm{C}$ to corroborate the initial hormone levels in large antral follicles as described later. Theca cells of antral follicles were washed with diethyl-pyrocarbonate (DEPC) water (Genbiotech, Buenos Aires, Argentina) to remove granulosa cells and stored at $-80^{\circ} \mathrm{C}$ until total RNA extraction.

For Western blot, small samples from antral follicles $(n=10)$ and adrenal glands $(n=5)$ were immediately frozen at $-80^{\circ} \mathrm{C}$.

For tissue culture, ovaries $(n=6)$ were processed as detailed below.

\section{Total RNA extraction}

Total RNA was isolated from granulosa and theca samples after treatment with TRIzol LS Reagent (Invitrogen, Life Technologies Corporation), according to the manufacturer's instructions, with slight modifications. Also, adrenal samples were processed as positive controls. Briefly, 50-100 mg of tissue or pellet of granulosa cells was homogenized with $750 \mu \mathrm{L}$ of TRIzol LS Reagent (Invitrogen) and incubated for $10 \mathrm{~min}$ at $25^{\circ} \mathrm{C}$. Then, RNA was obtained by vigorously homogenizing with chloroform and incubating for $15 \mathrm{~min}$ at $4^{\circ} \mathrm{C}$. After centrifugation at $12,000 \mathrm{~g}$, the aqueous phase was incubated overnight with an equal volume of isopropyl alcohol at $-20^{\circ} \mathrm{C}$ and centrifuged at $12,000 \mathrm{~g}$ to obtain the pellet of RNA, which was then washed with $75 \mathrm{vol} / \mathrm{vol}$ ethanol 
for $10 \mathrm{~min}$ at $4^{\circ} \mathrm{C}$. Alcohol was replaced by DEPC water (Genbiotech) and prewarmed at $60^{\circ} \mathrm{C}$. The extracted RNA was DNase treated with deoxyribonuclease I (Invitrogen) to eliminate contaminating DNA and was stored at $-80^{\circ} \mathrm{C}$ for further use.

\section{Reverse transcription}

First-strand cDNA was synthesized in a $20 \mu \mathrm{L}$ reaction mixture using $1 \mu \mathrm{g}$ of total RNA samples treated with DNase I (Invitrogen). The reaction tubes contained random hexamers $(1 \mu \mathrm{g} / \mathrm{L})$, dNTPs $(25 \mathrm{mM})$, reaction buffer $5 \times$, dithiothreitol $(0.1 \mathrm{M})$, ribonuclease inhibitor $(40 \mathrm{U} / \mu \mathrm{L})$ and $\mathrm{M}-\mathrm{MLV}$ reverse transcriptase $(200 \mathrm{U} / \mu \mathrm{L})$ (Invitrogen). The reverse transcription conditions were as described in a previous study (Amweg et al. 2011).

\section{PCR primer design}

Bovine sequences for CYP11B1, cytochrome P450 aromatase (CYP19A1) and cytochrome P450 17hydroxylase/17,20-lyase (CYP17A1) were obtained from GenBank (http://www.ncbi. nlm.nih.gov/Entrez/index.htm). Specific primers were designed using the PrimerSelect program in the LASERGENE software (DNAStar, Madison, WI, USA). The primers were purchased from Invitrogen, and the sequences are summarized in Table 1. Oligonucleotide primers and amplification products were tested using the Basic Local Alignment Search Tool (BLAST; http://www.ncbi.nlm.nih.gov/BLAST) software to confirm gene specificity and determine exon locations, assuring that they were not designed from any homologous regions coding for other genes. The primer sequences for CYP19A1 and CYP17A1 were designed and validated to confirm the purity of mRNA in granulosa and theca cells respectively (no cross-contamination) (Lagaly et al. 2008). Glyceraldehyde3-phosphate dehydrogenase $(G A P D H)$ was used as a housekeeping gene (Shibaya et al. 2007).

\section{End point PCR}

An optimized end point PCR protocol was used to analyze the mRNA expression of CYP19A1 and CYP17A1. PCR was carried out in a final volume of $25 \mu \mathrm{L}$ containing $10 \mathrm{ng}$ CDNA (previously quantified by the Qubit method (Invitrogen)),
$1.5 \mathrm{mM} \mathrm{MgCl}_{2}, 0.5 \mu \mathrm{M}$ forward primer, $0.5 \mu \mathrm{M}$ reverse primer, $0.2 \mathrm{mM} d \mathrm{NTP}$, Taq buffer $10 \times$ and $2 \mathrm{U}$ Taq polymerase ( $5 \mathrm{U} /$ $\mu \mathrm{L}$ ) (Invitrogen). The reaction conditions were as described in a previous study (Amweg et al. 2011). Only granulosa samples positive for CYP19A1 mRNA and negative for CYP17A1 mRNA and theca samples positive for CYP17A1 mRNA and negative for CYP19A1 mRNA expression were used to detect CYP11B1 mRNA expression. In addition, the negative control performed using water instead of cDNA controls was negative to the reaction and the positive control using adrenal tissue was positive for CYP11B1 mRNA.

\section{Real-time PCR}

An optimized real-time PCR protocol was used to analyze the mRNA expression of CYP1 1B1, using SYBR Green I (Invitrogen) technology in a LightCycler Detection System (Pfaffl 2001). Transcript levels were measured by relative quantitative realtime PCR using a StepOne Real-Time PCR System (Applied Biosystems, Life Technologies Corporation). For CYP11B1, the following standardized protocol was used: initial denaturation at $98^{\circ} \mathrm{C}$ for $3 \mathrm{~min}$, followed by 40 cycles of denaturation at $98^{\circ} \mathrm{C}$ for $5 \mathrm{~s}$, annealing at $58^{\circ} \mathrm{C}$ for $15 \mathrm{~s}$, extension at $72^{\circ} \mathrm{C}$ for $20 \mathrm{~s}$ and fluorescence reading at $80^{\circ} \mathrm{C}$ for $10 \mathrm{~s}$. A master mix of the reaction components was prepared using SYBR Green I (Invitrogen). Each PCR reaction was performed in a final volume of $20 \mu \mathrm{L}$ containing $4 \mu \mathrm{L}$ cDNA and $16 \mu \mathrm{L}$ of a reaction mixture: forward primer $(20 \mu \mathrm{M})$, reverse primer $(20 \mu \mathrm{M}), 0.2 \mathrm{mM}$ of each dNTP, $1 \mu \mathrm{L}$ SYBR Green I, $4 \mu \mathrm{L}$ buffer $5 \times$ and $0.05 \mu \mathrm{L}$ enzyme Phire (Hot Start II DNA Polymerase, Thermo Fisher Scientific Company). For GAPDH, the following standardized protocol was used: initial denaturation at $95^{\circ} \mathrm{C}$ for $10 \mathrm{~min}$, followed by 35 cycles of denaturation at $95^{\circ} \mathrm{C}$ for $15 \mathrm{~s}$, annealing at $52^{\circ} \mathrm{C}$ for $20 \mathrm{~s}$, extension at $72^{\circ} \mathrm{C}$ for $30 \mathrm{~s}$ and fluorescence reading at $74^{\circ} \mathrm{C}$ for $10 \mathrm{~s}$. Each PCR reaction was performed in a final volume of $20 \mu \mathrm{L}$ containing $4 \mu \mathrm{L} \mathrm{CDNA}$ and $16 \mu \mathrm{L}$ of a reaction mixture: forward primer $(20 \mu \mathrm{M})$, reverse primer $(20 \mu \mathrm{M}), 0.2 \mathrm{mM}$ of each $\mathrm{dNTP}, 1 \mu \mathrm{L}$ SYBR Green I, $2 \mu \mathrm{L}$ buffer TAQ 10×, $50 \mathrm{mM} \mathrm{Cl}_{2} \mathrm{Mg}$ and $0.32 \mu \mathrm{L}$ Taq DNA Polymerase (Invitrogen). All measurements for each sample were obtained in duplicate. The efficiency of the PCR and the relative quantities of cDNA were determined from a six-point standard curve. Standard curves were constructed from $50 \%$ serial dilutions of a cDNA mixture of granulosa

Table 1 Primer sequences, regions of the target genes and conditions used for real time RT-PCR.

\begin{tabular}{|c|c|c|c|c|c|c|}
\hline Name & Sequence $\left(5^{\prime}-3^{\prime}\right)$ & Gene accession no. & $\begin{array}{l}\text { Amplicon } \\
\text { position }\end{array}$ & $\begin{array}{l}\text { Amplicon size } \\
\text { (bp) }\end{array}$ & $\begin{array}{c}\text { Annealing temp. } \\
\left({ }^{\circ} \mathrm{C}\right)\end{array}$ & No. cycles \\
\hline \multicolumn{7}{|l|}{ CYP11B1 } \\
\hline Forward & СССТGАСАGССТGААСТTTА & NM 174638 & $656-767$ & 112 & 58 & 40 \\
\hline Reverse & ССТССАСАTGTTGGTGСTCA & & & & & \\
\hline \multicolumn{7}{|l|}{ GAPDH } \\
\hline Forward & CACССТCAAGATTGTCAGCA & BC102589 & $492-594$ & 103 & 52 & 35 \\
\hline Reverse & GGTCATAAGTCCCTCCACGA & & & & & \\
\hline \multicolumn{7}{|l|}{ CYP17 } \\
\hline Forward & GGAGGCGACCATCAGAGAAGTGC & NM_174304 & $1105-1423$ & 319 & 60.8 & 35 \\
\hline Reverse & CAGCCGGGACATGAAGAGGAAGAG & & & & & \\
\hline \multicolumn{7}{|c|}{ 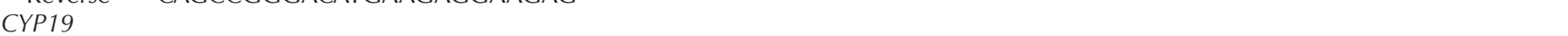 } \\
\hline Forward & TAAAACAAAGCGCCAATCTCTACG & BTCYP19 & $8-348$ & 341 & 55.4 & 35 \\
\hline Reverse & GGAACCTGCAGTGGGAAATGA & & & & & \\
\hline
\end{tabular}


and theca cells, and PCR efficiency was calculated using the StepOne software v2.2 (Applied Biosystems). In standard curves, R2: 0.99 for CYP11B1 and R2: 0.98 for GAPDH. About $20 \mathrm{ng}$ cDNA, previously quantified by the Qubit method (Invitrogen), was used. The mRNA expression levels of genes were recorded as cycle threshold $\left(C_{t}\right)$ values that corresponded to the number of cycles at which the fluorescence signal can be detected above a threshold value. The $C_{t}$ was calculated manually using StepOne v2.2 (Applied Biosystems). Negative DNA template controls were included in all the assays and yielded no consistent amplification. The purity of the product was confirmed by melting curve analysis to obtain a specific temperature dissociation product of $86.76^{\circ} \mathrm{C}$ and $85^{\circ} \mathrm{C}$ for CYP11B1 and GAPDH respectively. Random samples were subjected to agarose gel electrophoresis. Fold change was determined using the $2^{-\Delta \Delta C t}$ method (Livak \& Schmittgen 2001).

\section{Nucleotide sequencing}

The specificities of the PCR products were checked by direct sequencing to ensure amplification of the correct sequences using the Macrogen Sequencing Service (Macrogen, Korea). The resulting sequences were verified using the MegAlign tool in the LASERGENE software (DNAStar). Homology with bovine sequences was $98 \%$.

\section{Production of CYP11B1 antibody}

To evaluate CYP11B1 protein expression, an affinity-purified rabbit polyclonal antibody was generated using previously described protocols (Monje et al. 2009). The antigen was expressed in Escherichia coli JM109 (Stratagene Corp.) as a glutathione-S-transferase fusion protein, using a pGEX4T-3 vector (Stratagene). The 255-bp region formed between bases 370 and 624 was amplified from the coding sequence of bovine CYP11B1 (NM_174638.3). This region encodes the peptide GHKCGVFLLNGPQWRLDRLRLNPDVLSLPAL QKYTPLVDGVARDFSQTLKARVLQNARGSLTLGHRAQLF RYTIEASTLVLYGER belonging to the antigenic region of the molecule. The antibody was purified using antigen-linked affinity chromatography (Hi-Trap NHS activated HP column; GE Healthcare). The homology between the target peptide of the antibody and the corresponding bovine protein was tested with the BLAST software to determine the peptide location and to confirm antigen specificity.

\section{Western blot}

To determine CYP11B1 protein expression, bovine ovarian tissue and adrenal samples were homogenized in lysis buffer with a protease inhibitor cocktail (Complete Mini Protease Inhibitor Cocktail Tablets; Roche), as previously described (Salvetti et al. 2012). The proteins were separated by SDS-PAGE (12\% resolving gel) as described previously (Ortega et al. 2009, Salvetti et al. 2010). Proteins were transferred to nitrocellulose membranes (GE Healthcare), blocked for $5 \mathrm{~h}$ in $5 \% \mathrm{wt} / \mathrm{vol}$ nonfat milk in Tris-buffered saline that contained $0.05 \%$ vol/ vol Tween 20 (Sigma-Aldrich) and then incubated overnight at $4{ }^{\circ} \mathrm{C}$ with specific CYP11B1 polyclonal primary antibody at a 1:1000 dilution. After washing, membranes were treated for $1 \mathrm{~h}$ with the corresponding goat anti-rabbit $\lg \mathrm{G}$ peroxidaseconjugated antibody (Santa Cruz Biotechnology), at a 1:7500 dilution. The immunopositive bands were visualized with a chemiluminescent detection kit (ECL Prime Western Blotting Detection Reagent, GE Healthcare).

\section{Functionality of CYP11B1 in vitro: secretion of steroids by the follicular wall}

In a laminar flow hood, ovaries were rinsed, and large antral follicles were dissected using a scalpel. Follicular fluid from each selected follicle was aspirated and stored separately at $-20^{\circ} \mathrm{C}$ for $17 \beta$-estradiol, progesterone and testosterone determination to confirm their health status by the hormone levels.

Each large antral follicle was sectioned into five fragments of $100 \mathrm{mg}$ each (one fragment destined to culture basal and four fragments to be treated with $\mathrm{ACTH}$ ). The fragments were cultured on 24-well (1 mL medium/well) culture plates (Nunc plate, Applied Scientific, South San Francisco, CA, USA) and incubated in RPMI-1640 buffer (Gibco, ThermoFisher Scientific) with ascorbic acid 1\% (Gibco, ThermoFisher Scientific) and antibiotic/antimycotic $1 \%$ (Gibco, ThermoFisher Scientific). The culture medium of four fragments was supplemented with $100 \mathrm{nM}$ ACTH (Laboratorios ELEA, Buenos Aires, Argentina). This concentration has been described for a high cortisol secretion response in antral follicles in in vitro follicular wall cultures (Amweg et al. 2011). Additionally, three fragments were treated alternatively with $0.1,1$ or $10 \mu \mathrm{M}$ metyrapone (Sigma-Aldrich), an inhibitor of CYP11B1. As a control (basal secretion), tissues were incubated without the supplementation of ACTH or metyrapone. Each set of cultures $(n=6)$ was performed under identical conditions. The fragments were incubated for $7 \mathrm{~h}$ at $37^{\circ} \mathrm{C}$. Then, the culture medium was aspirated from each well and maintained at $-20^{\circ} \mathrm{C}$ until assayed.

\section{Hormone assays}

The concentrations of estradiol, progesterone, testosterone and cortisol in culture medium and of estradiol, progesterone and testosterone in follicular fluid were measured by electrochemiluminescence immunoassay kits (Roche Diagnostics $\mathrm{GmbH}$ ) in a cobas e411 system (Roche
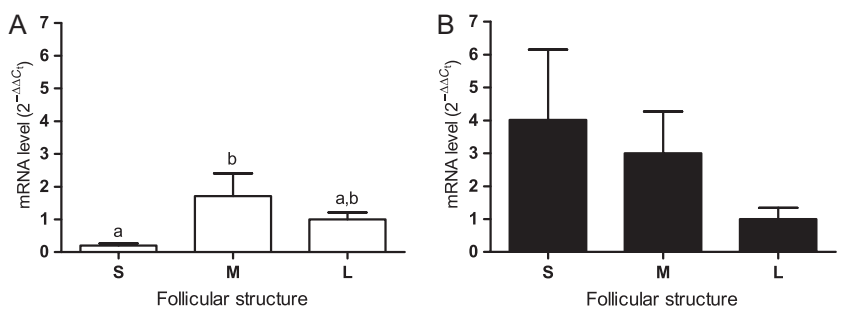

Figure 1 Relative quantification of CYP11B1 mRNA by real-time PCR in granulosa (A) and theca (B) cells of small (S), medium (M) and large (L) antral follicles. The $2^{-\Delta \Delta C t}$ values are represented as means \pm S.E.M. Bars with different letters are significantly different $(P<0.05)$. 
Diagnostics), according to the manufacturer's instructions and previous validation (Díaz et al. 2015). The assay sensitivity was $5 \mathrm{pg} / \mathrm{mL}$ for estradiol, $0.03 \mathrm{ng} / \mathrm{mL}$ for progesterone, $0.02 \mathrm{ng} / \mathrm{mL}$ for testosterone and $0.308 \mu \mathrm{g} / \mathrm{dL}$ for cortisol. According to the manufacturer's specifications, cortisol has $7 \%$ cross-reactivity with cortisone. The concentrations of 17-hydroxyprogesterone in culture medium were measured by a commercially available competitive RIA without extraction (Immunotech, Marseille, France) with a sensitivity of $0.05 \mathrm{ng} / \mathrm{mL}$.

Steroid concentrations in follicular fluid showed that all the large antral follicles used in the culture assays were estrogen active (estrogen:progesterone ratio $>1$ ) and non-atretic (estrogen:testosterone ratio $>1$ ).

\section{Statistical analyses}

The statistical software package SPSS 11.0 for Windows (SPSS) was used to analyze the results of steroid concentrations in culture medium. The differences between groups of data were assessed by one-way ANOVA, followed by Duncan's multiple range tests. Regression analysis was used to determine the concentration-response effects. For all statistical analyses, $P<0.05$ was considered significant. Results are expressed as means \pm S.E.M.

\section{Results}

\section{CYP11B1 gene expression}

CYP11B1 mRNA expression was compared in realtime PCR. GAPDH mRNA expression was similar in the different groups evaluated $(P>0.05)$, which confirmed that the cDNA quantities used were equivalent.

CYP11B1 mRNA was expressed in granulosa and theca cells in small, medium and large antral follicles (Fig. 1). CYP11B1 mRNA expression in granulosa cells was lower in small than that in medium antral follicles $(P<0.05$; Fig. 1A). In contrast, no significant differences in CYP11B1 mRNA expression were observed in the different follicular categories analyzed in theca cells $(P>0.05$; Fig. 1B).

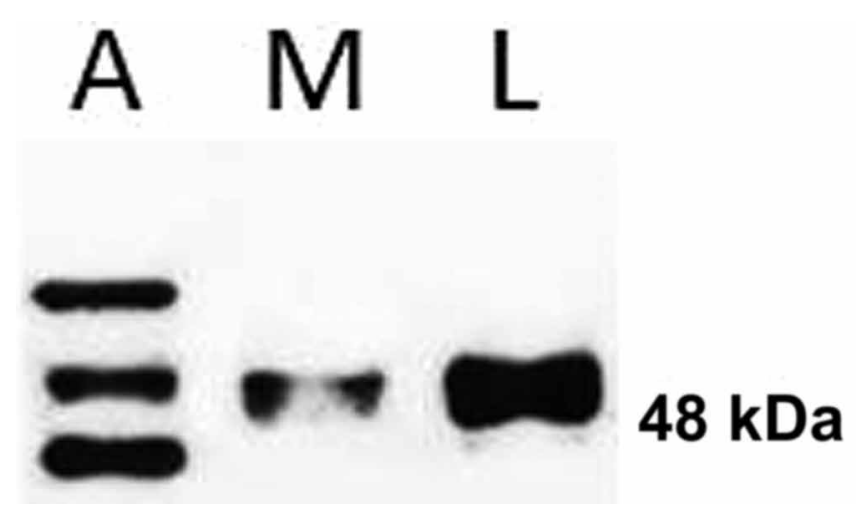

Figure 2 Representative image of a western blot showing expression of CYP11B1 of medium (M) and large (L) antral follicles and adrenal gland (A). The molecular weight of the mature form detected in follicular walls is indicated.
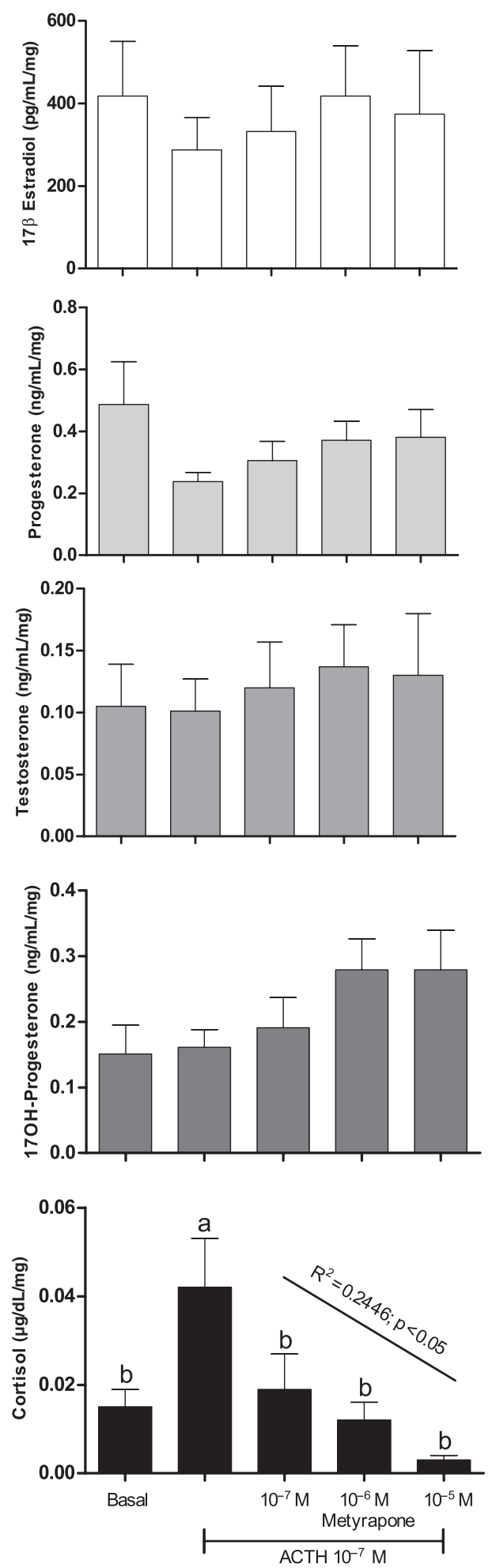

Figure 3 Effects of ACTH on the secretion of estradiol, progesterone, testosterone, 17-hydroxyprogesterone and cortisol by the follicular wall of large antral follicles. Bars represent the mean \pm S.E.M. Bars with different letters are significantly different $(P<0.05)$. Concentrationresponse effects are also indicated with a regression line. 


\section{CYP11B1 protein expression}

The expression of CYP11B1 by Western blot in bovine ovarian tissue and adrenal samples is showed in Fig. 2 . The CYP11B1 antibody recognized a band of $48 \mathrm{kDa}$, corresponding to the mature form of CYP11B1 enzyme, confirming the translation of mRNA detected by real-time PCR. On the other hand, in samples of bovine adrenal, a pattern of bands was obtained (Fig. 2) in agreement to that described by Morohashi (Morohashi et al. 1990).

\section{Functionality of CYP11B1 in vitro}

Steroid concentrations in the culture medium from the follicular wall of antral follicles are presented in Fig. 3. After $7 \mathrm{~h}$ of incubation, basal concentrations of secreted steroids were detected in all samples, with a significantly higher $(P<0.05)$ concentration of cortisol in the culture medium of ACTH-stimulated follicular wall portions relative to the control and those treated with different concentrations of metyrapone $(P<0.05)$. In response to metyrapone, the concentration of cortisol decreased in a concentration-dependent manner. This decrease was significant $(P<0.05)$ at $10^{-5} \mu \mathrm{M}$ metyrapone (Fig. 3).

\section{Discussion and conclusions}

In this study, we found clear evidence that mRNA and protein for CYP11B1 are expressed in bovine ovaries. This suggests that the ovary is an extra-adrenal site of GC synthesis. In this sense, Murata and coworkers (Murata et al. 2011) and Raghuveer and coworkers (Raghuveer et al. 2011) reported that CYP11B1 is expressed in gonads during sexual differentiation in fish. Also, Yazawa and coworkers (Yazawa et al. 2008) reported the expression of CYP11B1 mRNA and protein after human chorionic gonadotropin (hCG) treatment in murine testes and ovaries. On the other hand, Fru and coworkers (Fru et al. 2006) found no expression of CYP11B1 in the ovaries of rhesus macaques. These results differ from those found in our work in cattle. This could be because synthesis and metabolism of cortisol in the ovary of rhesus macaques may differ from those of cattle. 11-Deoxycortisol was not detectable in follicular fluid before hCG administration or at $3 \mathrm{~h}$ after hCG administration, and CYP11B1 mRNA was not detected before or after hCG administration. However, we showed that CYP11B1 mRNA was expressed in granulosa and theca cells in small, medium and large bovine antral follicles and that protein was expressed in medium and large antral follicles. Furthermore, a significant decrease in cortisol concentration was observed after inhibition by metyrapone. This is the first description of the expression of this key enzyme in the cortisol metabolism in the bovine ovary.

Ovulation involves active remodeling of the extracellular matrix (EMC) to facilitate follicle rupture prior to luteinization, to increase blood flow and vascular permeability, and to release the oocyte (Richards et al. 2008, Zackrisson et al. 2011). This process is considered similar to an inflammatory response, in which expression of many proinflammatory genes, including cytokines such as interleukin (IL)-1, IL-6, IL-8 and tumor necrosis factor- $\alpha$ (TNF- $\alpha$ ), is increased (Field et al. 2014). In addition, specific components of the ECM and basal membrane can be altered through cleavage by matrix metalloproteinases (MMPs), such as collagenase (i.e. MMP-1, -8 and -13) or gelatinase (MMP-2 and -9), whose activities are inhibited by tissue inhibitors of metalloproteinases (TIMPs) (Smith et al. 2002). Ovulation is a form of natural injury in which gonadotropin induces an inflammatory cascade within the ovary that terminates in proteolytic breakdown of the follicle wall and follicular rupture (Rae et al. 2009). The generation of anti-inflammatory GCs during ovulation would help to limit the inflammatory process in the ovary (Hillier \& Tetsuka 1998, Andersen 2002, Michael et al. 2003), and their actions could be due to a paracrine regulation of these hormones that may play an important physiological role in ovarian homeostasis. However, extreme situations could affect the normal ovulatory mechanism, altering the estrous cycle and blocking ovulation. In this sense, it has been demonstrated that ACTH increases endogenous cortisol secretion, thus inducing follicular persistence and cyst formation in cattle (Dobson et al. 2000, Salvetti et al. 2010, Amweg et al. 2013).

$\mathrm{ACTH}$ is produced by cleavage from its precursor pro-opiomelanocortin, and released into the circulation to act on peripheral sites, mainly the adrenal glands, to stimulate CYP11B1 transcription and GCs production. A significantly higher concentration of cortisol was observed in the culture medium of follicular wall stimulated with $\mathrm{ACTH}$, considering that a percentage could be due to the inert metabolite cortisone due to $7 \%$ of cross-reactivity of immunoassay. These results are consistent with those found previously in vitro by our group, where we showed that ACTH is able to stimulate the secretion of cortisol by the wall of ovarian follicles (Amweg et al. 2011, 2013). Moreover, we found the presence of MC2R in the bovine ovary, suggesting that ACTH may have an important role as a modulator of gonadal function via MC2R (Amweg et al. 2013). However, these results did not allow determining whether the increase in cortisol concentration was due to de novo synthesis or to conversion from cortisone by $11 \mathrm{BHSD}$. Nevertheless, the results of the present manuscript suggest that the bovine ovary could have de novo synthesis of GCs.

GCs have potent anti-inflammatory and immunosuppressive activity. Their action could not only be a product of the modulation between active and inactive forms of corticosteroids as had been described previously (Thurston et al. 2007, Tetsuka et al. 2010), 
also there is evidence that they are locally produced in extra-adrenal organs (Davies \& MacKenkie 2003, Taves et al. 2011, Vukelic et al. 2011, Kostadinova et al. 2014). Studies in the intestinal mucosa suggest that the intestinal expression of steroidogenic enzymes and the synthesis of GCs could be triggered in response to strong immune cell activation. This suggests a direct relationship between the activation of immune cells, the release of inflammatory mediators and the induction of steroidogenesis in the intestinal epithelium (Kostadinova et al. 2014). Thus, a contribution to the maintenance of local immune homeostasis and the regulation of inflammatory processes might be effective (Kostadinova et al. 2014). On the other hand, epidermal keratinocytes synthesize and secrete cortisol in vitro and in vivo and express CYP11B1, suggesting that epidermal synthesis of cortisol in situ constitutes a negative feedback mechanism to prevent the inflammatory response caused by epidermal injury (Vukelic et al. 2011).

CYP11B1 is required for the final step of GCs synthesis. Thus, we evaluated in vitro the functionality of this enzyme through metyrapone, a specific inhibitor of 11-hydroxylase activity, used to diagnose/treat hypercortisolism as well as to test the functional integrity of the HPA axis (Parthasarathy \& Balasubramanian 2008). We found significantly higher concentration of cortisol in the culture medium of ACTH-stimulated follicular wall relative to the control, and a concentrationdependent decrease in the concentration of cortisol, due to the inhibition by metyrapone. The results obtained in the in vitro study showed that the bovine ovary is able to respond to the $\mathrm{ACTH}$ released as a consequence to stress and also that the ovaries have steroidogenic enzymes responsible for the synthesis and secretion of GCs. Systems activated by stress can influence reproduction at the hypothalamus, pituitary gland or gonads (Tilbrook et al. 2000). Particularly, cortisol can affect reproduction through its actions at the hypothalamic level, affecting the secretion of gonadotropin-releasing hormone in the pituitary gland by inhibiting the secretion of gonadotropins, especially LH, and in the ovaries, by affecting the ovarian functions (Tilbrook et al. 2000, Tetsuka et al. 2010, Ralph et al. 2016). Based on the results here obtained, we propose that CYP11B1 could synthesize cortisol which is then able to exert local anti-inflammatory actions in the bovine ovary. Also, these actions could be additionally regulated in the ovary by the availability of active cortisol via 11BHSD (Tetsuka et al. 2010). In this sense, we have previously demonstrated that all follicular stages in the bovine ovary express 11BHSD1 and 11BHSD2 (Amweg et al. 2013) with increased expression of 11BHSD1 in granulosa as follicles mature (Amweg et al. 2013).

In the bovine ovary, the high expression of TNF- $\alpha$ found in the granulosa cells of primary and preantral bovine follicles and low expression in the granulosa cells of antral and atretic follicles (Baravalle et al. 2015) could be related to the presence of CYP11B1 able to synthesize cortisol, as we demonstrated in ACTHstimulated bovine ovary. In addition, previous studies have demonstrated a high expression of glucocorticoid receptor in the granulosa cells from atretic follicles in relation to that in primary, secondary and tertiary follicles, as well as to that in the theca interna cells of all follicular categories (Amweg et al. 2016). In this sense, after the interaction with glucocorticoid receptor, GCs are able to inhibit the synthesis of multiple inflammatory proteins through suppression of the genes that encode them (Cosío et al. 2005, Barnes 2006).

In conclusion, this study demonstrated that CYP11B1 is present in the bovine ovary. This confirms that there could be a local synthesis of GCs in the bovine ovary and therefore a potential endocrine response to stress through these hormones. An increase in the local concentration of GCs in the ovary could play a protective mechanism to control the deleterious effects of excessive production of inflammatory mediators. Moreover, through their anti-inflammatory effects, local GCs may be involved in the regulatory mechanisms related to ovulation, ovarian steroidogenesis and luteal function.

\section{Declaration of interest}

The authors declare that there is no conflict of interest that could be perceived as prejudicing the impartiality of the research reported.

\section{Funding}

This study was supported by grants from the Argentine National Agency for the Promotion of Science and Technology (ANPCyT) (PICTs 2011-1274, 2014-2540) and from the National University of Litoral (CAID Program).

\section{Acknowledgments}

Technical assistance of Dr M Zayas and veterinary advice from Dr P Díaz of the Instituto de Ciencias Veterinarias del Litoral is gratefully acknowledged.

\section{References}

Amweg AN, Paredes AH, Salvetti NR, Lara HE \& Ortega HH 2011 Expression of melanocortin receptors mRNA, and direct effects of ACTH on steroid secretion in the bovine ovary. Theriogenology 75 628-637. (doi:10.1016/j.theriogenology.2010.10.003)

Amweg AN, Salvetti NR, Stangaferro ML, Paredes AH, Lara HE, Rodríguez FM \& Ortega HH 2013 Ovarian localization of $11 \beta$-hydroxysteroid dehydrogenase $(11 \beta \mathrm{HSD})$ : effects of ACTH stimulation and its relationship with bovine cystic ovarian disease. Domestic Animal Endocrinology 45 126-140. (doi:10.1016/j. domaniend.2013.07.001)

Amweg AN, Rodríguez FM, Huber E, Marelli BE, Salvetti NR, Rey F \& Ortega HH 2016 Role of glucocorticoids in cystic ovarian 
disease: expression of glucocorticoid receptor in the bovine ovary. Cells Tissues Organs 201 138-147. (doi:10.1159/000442150)

Andersen CY 2002 Possible new mechanism of cortisol action in female reproductive organs: physiological implications of the free hormone hypothesis. Journal of Endocrinology 173 211-217. (doi:10.1677/ joe.0.1730211)

Asser L, Hescot S, Viengchareun S, Delemer B, Trabado S \& Lombès $M$ 2014 Autocrine positive regulatory feedback of glucocorticoid secretion: glucocorticoid receptor directly impacts H295R human adrenocortical cell function. Molecular and Cellular Endocrinology 395 1-9. (doi:10.1016/j.mce.2014.07.012)

Baravalle ME, Stassi AF, Velázquez MM, Belotti EM, Rodríguez FM, Ortega HH \& Salvetti NR 2015 Altered expression of pro-inflammatory cytokines in ovarian follicles of cows with cystic ovarian disease. Journal of Comparative Pathology 153 116-130. (doi:10.1016/j. jcpa.2015.04.007)

Barnes PJ 2006 Corticosteroid effects on cell signalling. European Respiratory Journal 27 413-426. (doi:10.1183/09031936.06.00125404)

Charmandari E, Tsigos C \& Chrousos G 2005 Endocrinology of stress response. Annual Review of Physiology 67 259-284. (doi:10.1146/ annurev.physiol.67.040403.120816)

Cosío BG, Torrego A \& Adcock IM 2005 Mecanismos moleculares de los glucocorticoides. Archivos de Bronconeumología 41 34-41. (doi:10.1157/13070282)

Davies E \& MacKenzie SM 2003 Extra-adrenal production of corticosteroids. Clinical and Experimental Pharmacology and Physiology 30 437-445. (doi:10.1046/j.1440-1681.2003.03867.x)

Dejager L, Vandevyver S, Petta I \& Libert C 2014 Dominance of the strongest: inflammatory cytokines versus glucocorticoids. Cytokine and Growth Factor Reviews 25 21-33. (doi:10.1016/j.cytogfr.2013.12.006)

Díaz PU, Stangaferro ML, Gareis NC, Silvia WJ, Matiller V, Salvetti NR, Rey F, Barberis F, Cattaneo L \& Ortega HH 2015 Characterization of persistent follicles induced by prolonged treatment with progesterone in dairy cows: an experimental model for the study of ovarian follicular cysts. Theriogenology 84 1149-1160. (doi:10.1016/j. theriogenology.2015.06.015)

Dobson H, Ribadu AY, Noble KM, Tebble JE \& Ward WR 2000 Ultrasonography and hormone profiles of adrenocorticotrophic hormone (ACTH)-induced persistent ovarian follicles (cysts) in cattle. Journal of Reproduction and Fertility 120 405-410. (doi:10.1530/ reprod/120.2.405)

Duong HT, Piotrowska-Tomala KK, Acosta TJ, Bah MM, Sinderewicz E, Majewska M, Jankowska K, Okuda K \& Skarzynski DJ 2012 Effects of cortisol on pregnancy rate and corpus luteum function in heifers: an in vivo study. Journal of Reproduction and Development 58 223-230. (doi:10.1262/jrd.11-122T)

Field SL, Dasgupta T, Cummings M \& Orsi NM 2014 Cytokines in ovarian folliculogenesis, oocyte maturation and luteinisation. Molecular Reproduction and Development 81 284-314. (doi:10.1002/mrd.22285)

Fru KN, VandeVoort CA \& Chaffin CL 2006 Mineralocorticoid synthesis during the periovulatory interval in macaques. Biology of Reproduction 75 568-574. (doi:10.1095/biolreprod.106.053470)

Hillier SG \& Tetsuka M 1998 An anti-inflammatory role for glucocorticoids in the ovaries? Journal of Reproductive Immunology 39 21-27. (doi:10.1016/S0165-0378(98)00011-4)

Hu J, Zhang Z, Shen WJ \& Azhar S 2010 Cellular cholesterol delivery, intracellular processing and utilization for biosynthesis of steroid hormones. Nutrition and Metabolism 7 47. (doi:10.1186/17437075-7-47)

Kostadinova F, Schwaderer J, Sebeo V \& Brunner T 2014 Why does the gut synthesize glucocorticoids? Annals of Medicine 46 490-497. (doi:10.31 09/07853890.2014.932920)

Krozowski Z, Li KX, Koyama K, Smith RE, Obeyesekere VR, Stein-Oakley A, Sasano H, Coulter C, Cole T \& Sheppard KE 1999 The type I and type II 11 beta-hydroxysteroid dehydrogenase enzymes. Journal of Steroid Biochemistry 69 391-401. (doi:10.1016/S09600760(99)00074-6)

Kuse M, Lee HY, Acosta TJ, Hojo T \& Okuda K 2013 Expression of glucocorticoid receptor $\alpha$ and its regulation in the bovine endometrium: possible role in cyclic prostaglandin $\mathrm{F} 2 \alpha$ production. Journal of Reproduction and Development 59 346-352. (doi:10.1262/jrd.2012-185)
Lagaly D, Aad PY, Grado-Ahuir JA, Hulsey LB \& Spicer LJ 2008 Role of adiponectin in regulating ovarian theca and granulosa cell function. Molecular and Cellular Endocrinology 284 38-45. (doi:10.1016/j. mce.2008.01.007)

Livak KJ \& Schmittgen TD 2001 Analysis of relative gene expression data using real-time quantitative PCR and the $2^{-\Delta \Delta C T}$ method. Methods 25 402-408. (doi:10.1006/meth.2001.1262)

Michael AE, Evagelatou M, Norgate DP, Clarke RJ, Antoniw JW, Stedman BA, Brennan A, Welsby R, Bujalska I, Stewart PM et al. 1997 Isoforms of 11beta-hydroxysteroid dehydrogenase in human granulosa-lutein cells. Molecular and Cellular Endocrinology 132 43-52. (doi:10.1016/S0303-7207(97)00118-4)

Michael AE, Thurston LM \& Rae MT 2003 Glucocorticoid metabolism and reproduction: a tale of two enzymes. Reproduction 126 425-441. (doi:10.1530/rep.0.1260425)

Magomedova L \& Cummins CL 2016 Glucocorticoids and metabolic control. Handbook of Experimental Pharmacology 233 73-93. (doi:10.1007/164_2015_1)

Majewska M, Lee HY, Tasaki Y, Acosta TJ, Szostek AZ, Siemieniuch M, Okuda K \& Skarzynski DJ 2012 Is cortisol a modulator of interferon tau action in the endometrium during early pregnancy in cattle? Journal of Reproductive Immunology 93 82-93. (doi:10.1016/j.jri.2012.01.004)

Monje L, Varayoud J, Muñoz-de-Toro M, Luque EH \& Ramos JG 2009 Neonatal exposure to bisphenol A alters estrogen-dependent mechanisms governing sexual behavior in the adult female rat. Reproductive Toxicology 28 435-442. (doi:10.1016/j.reprotox.2009.06.012)

Morohashi K, Nonaka Y, Kirita S, Hatano O, Takakusu A, Okamoto M \& Omura T 1990 Enzymatic activities of P-450(11 beta)s expressed by two cDNAs in COS-7 cells. Journal of Biochemistry 107 635-640.

Murata R, Karimata H, Kobayashi Y, Horiguchi R, Kishimoto K, Kimura M, Kobayashi T, Soyano K \& Nakamura M 2011 Differentiation of steroid-producing cells during ovarian differentiation in the protogynous Malabar grouper, Epinephelus malabaricus. International Journal of Developmental Biology 55 619-625. (doi:10.1387/ijdb.103181rm)

Myers M, Lamont C, van den Driesche S, Mary N, Thong KJ, Hillier SG \& Duncan WC 2007 Role of luteal glucocorticoid metabolism during maternal recognition of pregnancy in women. Endocrinology 148 5769-5779. (doi:10.1210/en.2007-0742)

Nemeth M, Millesi E, Wagner KH \& Wallner B 2014 Effects of diets high in unsaturated Fatty acids on socially induced stress responses in Guinea pigs. PLoS ONE 9 e116292. (doi:10.1371/journal.pone.0116292)

Nicolaides NC, Galata Z, Kino T, Chrousos GP \& Charmandari E 2010 The human glucocorticoid receptor: molecular basis of biologic function. Steroids 75 1-12. (doi:10.1016/j.steroids.2009.09.002)

Novoselova TV, Jackson D, Campbell DC, Clark AJL \& Chan LF 2013 Melanocortin receptor accessory proteins in adrenal gland physiology and beyond. Journal of Endocrinology 217 1-11. (doi:10.1530/JOE-120501)

Ortega HH, Salvetti NR \& Padmanabhan V 2009 Developmental programming: prenatal androgen excess disrupts ovarian steroid receptor balance. Reproduction 137 865-877. (doi:10.1530/REP-08-0491)

Parrott JA \& Skinner MK 1998 Developmental and hormonal regulation of keratinocyte growth factor expression and action in the ovarian follicle. Endocrinology 139 228-235. (doi:10.1210/en.139.1.228)

Parthasarathy C \& Balasubramanian K 2008 Effects of corticosterone deficiency and its replacement on Leydig cell steroidogenesis. Journal of Cellular Biochemistry 104 1671-1683. (doi:10.1002/jcb.21733)

Pfaffl MW 2001 A new mathematical model for relative quantification in real-time RTPCR. Nucleic Acids Research 29 e45. (doi:10.1093/ nar/29.9.e45)

Rae MT, Price D, Harlow CR, Critchley HO \& Hillier SG 2009 Glucocorticoid receptor-mediated regulation of MMP9 gene expression in human ovarian surface epithelial cells. Fertility and Sterility 92 703708. (doi:10.1016/j.fertnstert.2008.06.040)

Yazawa T, Uesaka $M$, Inaoka $Y$, Mizutani T, Sekiguchi T, Kajitani T, Kitano T, Umezawa A \& Miyamoto K 2008 Cyp11b1 is induced in the murine gonad by luteinizing hormone/human chorionic gonadotropin and involved in the production of 11-ketotestosterone, a major fish androgen: conservation and evolution of the androgen metabolic pathway. Endocrinology 149 1786-1792. (doi:10.1210/ en.2007-1015) 
Raghuveer K, Senthilkumaran B, Sudhakumari CC, Sridevi P, Rajakumar A, Singh R, Murugananthkumar R \& Majumdar KC 2011 Dimorphic expression of various transcription factor and steroidogenic enzyme genes during gonadal ontogeny in the air-breathing catfish Clarias gariepinus. Sexual Development 5 213-223. (doi:10.1159/000328823)

Ralph C, Lehman M, Goodman RL \& Tilbrook A 2016 Impact of psychosocial stress on gonadotropins and sexual behaviour in females: role for cortisol? Reproduction 152 R1-R14. (doi:10.1530/REP-15-0604)

Richards JS, Liu Z \& Shimada M 2008 Immune-like mechanisms in ovulation. Trends in Endocrinology and Metabolism 19 191-196. (doi:10.1016/j.tem.2008.03.001)

Salvetti NR, Stangaferro ML, Palomar MM, Alfaro NS, Rey F, Gimeno EJ \& Ortega HH 2010 Cell proliferation and survival mechanisms underlying the abnormal persistence of follicular cysts in bovines with cystic ovarian disease induced by ACTH. Animal Reproduction Science 122 98-110. (doi:10.1016/j.anireprosci.2010.08.003)

Salvetti NR, Alfaro NS, Velázquez MM, Amweg AN, Matiller V, Díaz PU \& Ortega HH 2012 Alteration in localization of steroid hormone receptors and coregulatory proteins in follicles from cows with induced ovarian follicular cysts. Reproduction 144 723-735. (doi:10.1530/REP-12-0188)

Schiffer L, Anderko S, Hannemann F, Eiden-Plach A \& Bernhardt R 2015 The CYP11B subfamily. Journal of Steroid Biochemistry and Molecular Biology 151 38-51. (doi:10.1016/j.jsbmb.2014.10.011)

Schmidt KL, Chin EH, Shah AH \& Soma KK 2009 Cortisol and corticosterone in immune organs and brain of European starlings: developmental changes, effects of restraint stress, comparison with zebra finches. American Journal of Physiology: Regulatory, Integrative and Comparative Physiology 297 42-51. (doi:10.1152/ajpregu.90964.2008)

Shibaya M, Matsuda A, Hojo T, Acosta TJ \& Okuda K 2007 Expressions of estrogen receptors in the bovine corpus luteum: cyclic changes and effects of prostaglandin F2alpha and cytokines. Journal of Reproduction and Development 53 1059-1068. (doi:10.1262/jrd.19065)

Simerman AA, Hill DL, Grogan TR, Elashoff D, Clarke NJ, Goldstein EH, Manrriquez AN, Chazenbalk GD \& Dumesic DA 2015 Intrafollicular cortisol levels inversely correlate with cumulus cell lipid content as a possible energy source during oocyte meiotic resumption in women undergoing ovarian stimulation for in vitro fertilization. Fertility and Sterility 103 249-257. (doi:10.1016/j.fertnstert.2014.09.034)

Smith MF, Ricke WA, Bakke LJ, Dow MP \& Smith GW 2002 Ovarian tissue remodeling: role of matrix metalloproteinases and their inhibitors. Molecular and Cellular Endocrinology 191 45-56. (doi:10.1016/S03037207(02)00054-0)

Taves MD, Gomez-Sanchez CE \& Soma KK 2011 Extra-adrenal glucocorticoids and mineralocorticoids: evidence for local synthesis, regulation, and function. American Journal of Physiology, Endocrinology and Metabolism 301 11-24. (doi:10.1152/ajpendo.00100.2011)

Tetsuka M 2007 Actions of glucocorticoid and their regulatory mechanisms in the ovary. Animal Science 7 112-120. (doi:10.1111/j.17400929.2007.00414.x)

Tetsuka M, Yamamoto S, Hayashida N, Hayashi KG, Hayashi M, Acosta TJ \& Miyamoto A 2003 Expression of 11beta-hydroxysteroid dehydrogenases in bovine follicle and corpus luteum. Journal of Endocrinology 177 445-452. (doi:10.1677/joe.0.1770445)

Tetsuka M, Nishimoto H, Miyamoto A, Okuda K \& Hamano S 2010 Gene expression of $11 \beta-\mathrm{HSD}$ and glucocorticoid receptor in the bovine (Bos taurus) follicle during follicular maturation and atresia: the role of follicular stimulating hormone. Journal of Reproduction and Development 56 616-622. (doi:10.1262/jrd.10-019K)

Thurston LM, Abayasekara DR \& Michael AE 2007 11b-Hydroxysteroid dehydrogenase expression and activities in bovine granulosa cells and corpora lutea implicate corticosteroids in bovine ovarian physiology. Journal of Endocrinology 193 299-310. (doi:10.1677/ joe.1.07025)

Tilbrook AJ, Turner AI \& Clarke IJ 2000 Effects of stress on reproduction in non-rodent mammals: the role of glucocorticoids and sex differences. Reviews of Reproduction 5 105-113. (doi:10.1530/ ror.0.0050105)

Vukelic S, Stojadinovic O, Pastar I, Rabach M, Krzyzanowska A, Lebrun E, Davis SC, Resnik S, Brem H \& Tomic-Canic M 2011 Cortisol synthesis in epidermis is induced by IL-1 and tissue injury. Journal of Chemical Biology 286 10265-10275. (doi:10.1074/jbc. M110.188268)

Xing Y, Parker CR, Edwards M \& Rainey WE 2010 ACTH is a potent regulator of gene expression in human adrenal cells. Journal of Molecular Endocrinology 45 59-68. (doi:10.1677/JME-10-0006)

Zackrisson U, Löfman CO, Janson PO, Wallin A, Mikuni M \& Brännström M 2011 Alterations of follicular microcirculation and apex structure during ovulation in the rat. European Journal of Obstetrics, Gynecology and Reproductive Biology 157 169-174. (doi:10.1016/j. ejogrb.2011.03.025)

Received 6 September 2016

First decision 6 October 2016

Revised manuscript received 2 January 2017

Accepted 9 January 2017 